\title{
Web-Based Information System of Psychological Test Employee Acceptance
}

\author{
Yustinus Feri Irawan, Phong Thanh Nguyen, S. Rema Devi, K. Shankar, Satria Abadi, Wahidah \\ Hashim, Andino Maseleno
}

\begin{abstract}
In every institution, it is definitely needed employees workers who manage the company so that it can run the activities of companies that use HR (Human Resources) one of them is in the education field, it needs workers who manage it, so that it can run teaching and learning activities well. In the procurement of labor or employees that must be really selective, to maximize performance in their respective duties. The development of technology is very possible that the information system is not only used as a tool for the implementation of the lecture process but it can also be used in the implementation of the web-based recruitment test. A web-based information system will be designed and developed to enable the employee selection process in a psychological test to be more selective and easier.
\end{abstract}

Keywords : psychological test, institution, selective.

\section{INTRODUCTION}

With current technological advances and the development of science, it will help humans in completing their tasks [1]. One of them is to take advantage to facilitate the psychological examination of employee recruitment. It is expected that this process can be carried out more efficiently and effectively and it can help in decision making [2].

The ability of communication between one field and another in different places (separated at great distances) is one of the characteristics of further globalization era [3]. While the main pillar of communication technology is computer technology that is in the form of computer equipment and accessories, 'networking' technology between the equipment, and software and operators (human resources) that use these equipment [4]. At the time, the quality of a particular life system will be determined by its ability to process communication that also means as the ability to have the best computer technology [5].

The writing data is almost one ordinary book cabinet.

Revised Manuscript Received on July 22, 2019

* Correspondence Author

Yustinus Feri Irawan, Department of Information Systems, STMIK Pringsewu, Lampung, Indonesia.

Phong Thanh Nguyen*, Department of Project Management, Ho Chi Minh City Open University, Vietnam. E-mail: phong.nt@ou.edu.vn

S. Rema Devi, Associate Professor and Head Department of English, Kalasalingam Academy of Research and Education, Krishnankoil, India. E-mail: remadevi.s@klu.ac.in

K. Shankar, Department of Computer Applications, Alagappa University, Karaikudi, India.

Satria Abadi, Department of Information Systems, STMIK Pringsewu, Lampung, Indonesia.

Wahidah Hashim, Institute of Informatics and Computing Energy, Universiti Tenaga Nasional, Malaysia

Andino Maseleno, Institute of Informatics and Computing Energy, Universiti Tenaga Nasional, Malaysia
Even if it is more sophisticated like CD technology used. It can be done between far away places and happened very quickly [6]. In accordance with current technological developments, the development of academic information systems has led to the use of web-based information technology, where all information contained in the system can be displayed using Internet media [7].

Employee performance and loyalty greatly affect the progress of relevant agencies [8]. Nothing else in the Academic organizational system in which there must be Human Resources (HR) or qualified teaching staff. Today, almost all companies use Psychology Tests as part of the recruitment of prospective employees [9]. Because of these factors it can distort the logical calculation of one's potential. Many people have high academic intelligence, but few of them are balanced between academic intelligence and emotional intelligence [10]. So it is not uncommon that many agencies find it very difficult to advance their quality because employees are less professional in their duties. Especially in the education world where the task is to provide knowledge to their students. It must be professional and with high work loyalty [11]. Because they will be an example of their students later. If the employee works in the administration field, he must also be able to do his tasks well so that the administration of the agency can run well and be organized [12]

\section{ANALYSIS AND DESIGN OF SOFTWARE}

In the software analysis and design phase, several steps are needed, including:

- Requirement determination

- Functional modeling

\subsection{Requirement Determination}

In the analysis phase the first thing to do is to determine the system requirements [13]. In the employee psychological test there are several functional needs, including:

Requirements that must be met

- Types of tests used

- Employee selection committee

In addition to functional requirements, there are also some non-functional requirements that must be included in the system to support the employee selection process [14] in the employee psychology test, including:

System and information can be accessed by public. 


\section{METHODS USED}

This study used some data collection namely :

- Observation Method

- Interview Method

- Questionnaire method

\subsection{Observation Method}

In the observation method, research on how the interests and desires of prospective employees with their work, and it can contribute to the loyalty of prospective employees to their work [15].

\subsection{Interview Method}

In the interview process, it is expected to be able to assess both the attitude and behavior of prospective employees. In interviews, it can be seen personality and mentality of the candidates [16].

\subsection{Questionnaire method}

The use of the questionnaire method is intended to obtain an overview of the procedures for employee psychological testing [17]. In the implementation, it must be balanced between the incoming questionnaire and the condition of the relevant agencies [18]. The use of the questionnaire method is expected to be used as a reference or basis for decisions taken, so that selected employees can be truly cooperative [19].

\section{RESULTS AND DISCUSSION}

From this research, it resulted several designs that can be used as an illustration in making web-based employee psychological test applications so that it will facilitate the implementation of the design in the programs used in making the application [20]. The design is as follows:

Home page

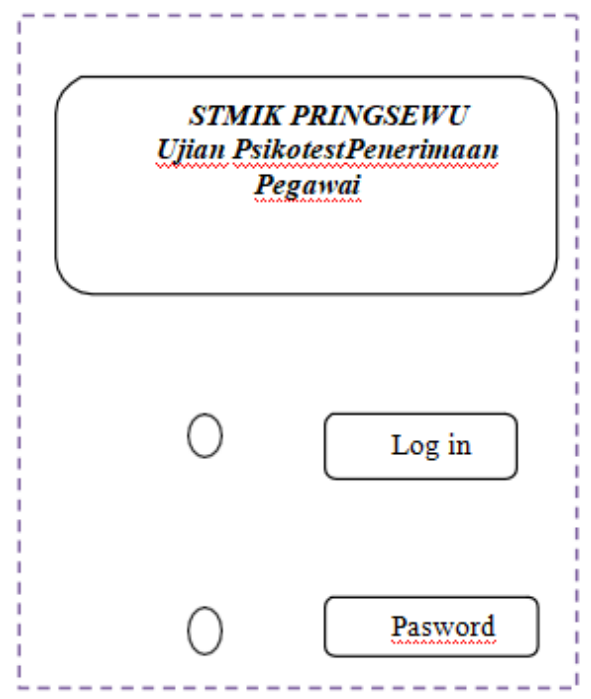

Figure 1. Home page

From the Main Page There is a Log in and Password menu where prospective employees must submit a file to the personnel department before given a Password and test participant number as evidence of participating in the selection of employee especially in psychology. With this application it is expected to bring order to the implementation of the web-based psychological test, so that it will minimize the occurrence of frauds that will reduce the effectiveness in using this application.

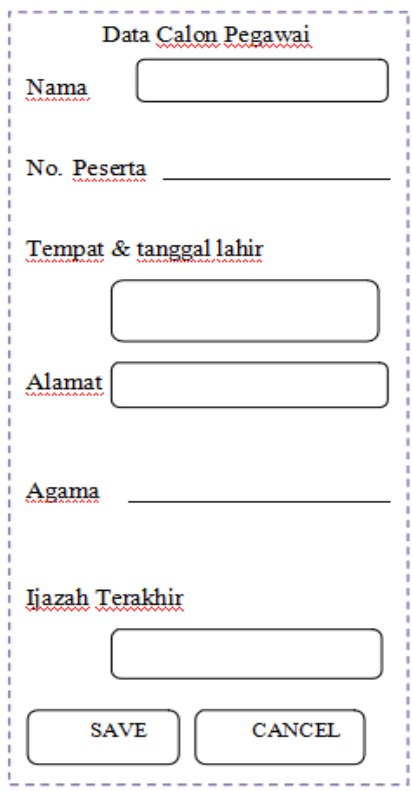

Figure2. Identity Page

In this prospective employees must fill the data in the fields provided, this is useful to match the data that has been submitted previously. From some of the existing columns it will be used as a consideration in the recruitment of employees, one of which is the data about educational background of prospective employees.

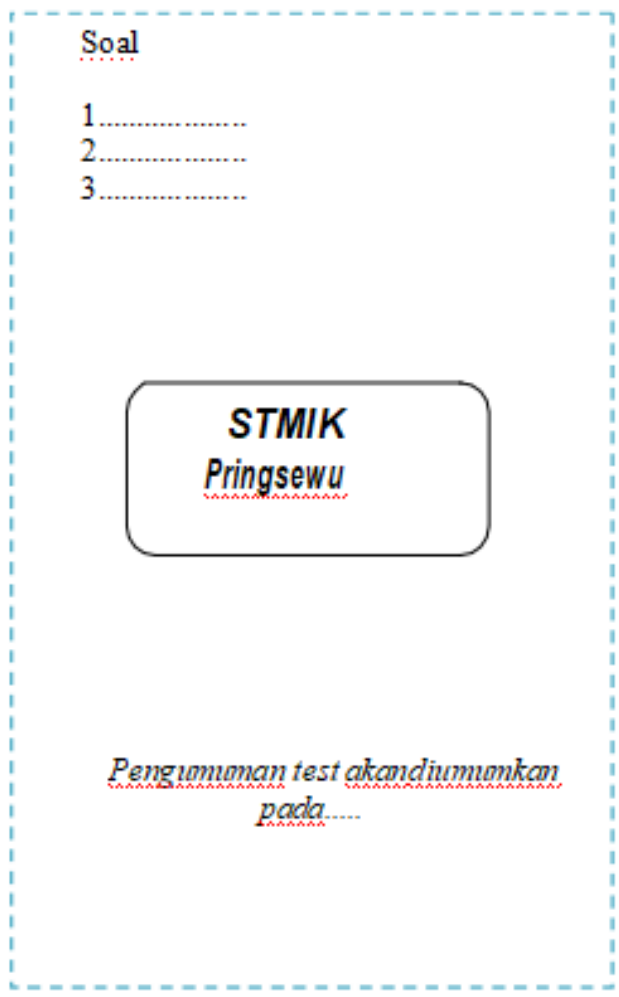

Figure3. Problem Tested 
On the next page, Questions that will be filled by prospective employees, where there are questions used as an assessment of the eligibility of prospective employees, as well as information about further announcements that can be seen by prospective employees and can be used as further information. The questions given are multiple choices in making it easier for prospective employees to solve the problems given

At this stage a place to store data on the server that will be prepared, the data will later be processed by the program at the programming stage when we make it. In addition, reduction, update, and display database contents in web pages. For the database that will be created will consist of several tables using MySQL as the database program. By using this data base can help the design of web-based psychological test that can provide convenience in handling things that will occur in the socialization of this application. The data base is as follows:

Table 1. Guest Book Database

\begin{tabular}{|ll|}
\hline ID BUKUTAMU & INTEGER \\
NAMA & VAR (40) \\
EMAIL & VAR (50) \\
KOMENTAR & TEXT (250) \\
\hline
\end{tabular}

Table 2. Database of Test Participants

PESERTA UJIAN

$\begin{array}{lc}\text { No.PESERTA } & \text { INTEGER NAMA } \\ \text { PESERTA } & \text { VAR (30) } \\ \text { ALAMAT PESERTA VAR (40) TAHUN_ } \\ \text { IJAZAH }\end{array}$

Table 3 . Login User Database

\begin{tabular}{|ll|}
\hline \multicolumn{2}{|c|}{ LOGIN USER } \\
\hline ID_PROFIL & INTEGER \\
USERNAME & VAR (30) \\
\hline
\end{tabular}

Table 4. Question Database

\begin{tabular}{|ll|}
\hline \multicolumn{2}{|c|}{ LEMBAR SOAL } \\
\hline KODE SOAL & INTEGER \\
ISI SOAL & TEXT \\
JENIS SOAL & VAR(30) \\
WAKTU & DATE \\
\hline
\end{tabular}

Description:

This design requires several tables that will support the smooth running of this application, the details are as follows:

\section{Guest Book}

In the guest book database design, the guestbook id uses an integer because the id is created using numbers. Comment using text so that filling in comments can be filled in a large number of words. while names and emails use varchar because they can be filled with characters.

\section{Test Participant}

In this database design there are no participant numbers used as primary keys, ie one participant only has one participant number. whereas in the year of diploma using date, it is in the form of date.

\section{User Login}

As explained above Id_Profil uses an integer and the Username uses Varchar

\section{Question}

In this table the problem uses text because it contains a lot of text.

Every file has the key and a file in the form of a field or a set of fields that can represent a record. There are two important key attributes:

a.Primary key is an attribute or a minimum set of attributes that is not only uniquely identifies a specific event, but also can represent an event of an entity.

\section{b.Foreign key}

Foreign key is an attribute that completes a relationship that shows its origin.

To develop an Information System Design for Web-Based Academic Psychology Test, it requires hardware and software to support the system, the supporting tools are:

\section{Computer}

One Computer Server Unit that will be installed on a network operating system, for example LINUX / FREE BSD

2.Network Equipment

Switches or hubs and cabling are needed to connect one computer to another.

\section{Software}

Using Apache Web Server, and MYSQL database

4. Internet Connection to Internet for dedicated server Facilities and infrastructure needed.

Physical facilities and infrastructure

1. One or more PC units

2. One or more printer to print data.

3. Spaces and computer desks (use existing tables and rooms).

4. Diskette, USB Flashdisk and others. 
Non physical facilities and infrastructure

1. Operating system and some application software

2. Basic computer system knowledge (for administrators and operators).

3. Human data, and administration required.

The I / O design uses Msql because MySQL has a number of tools; one of them is: the mysql program that is used to access the database from the client side of the mysqladmin program, to manage MySQL from the system administrator's side The advantage of using MySQL

- Portability: runs stable on various operating systems (Windows, Linux, Mac OS, Solaris etc.)

- Open Source : distributed freely

- Multiuser : can be used by several users at the same time without experiencing problem or conflict

- Public can provide input on policies made by the government so that it can improve government performance.

From the description above it can be taken several advantages in the application of web-based employee psychological test, namely:

- Web-based system is more efficient than the old system, because online exams provide flexibelity in choosing test location, so that the admissions committee or personnel department does not need to provide a special place for the exams [21].

- Web-based system is easier than the old system manually [22]. In the old it has to do manually so that it requires printing questions, while this new system prospective employees can directly fill in the pages provided.

- Web-based system is more sophisticated can ease the personnel section in monitoring the implementation of the exam [23].

- Web-based system have several values of effectiveness including direct evaluation of how prospective employees use technology.

- Web-based system provides new insights to the community about technological progress that can be applied in various ways, including the employee selection stage and of gives its own added value.

\section{CONCLUSION AND SUGGESTION}

\subsection{Conclusion}

From the results of the research and design above, it can be concluded that in the web-based employee psychological test it is expected to provide efficiency and effectiveness in the work world so as to provide convenience for users of information technology and it can be implemented in applications that can be accessed generally and provide convenience for users.

\subsection{Suggestion}

The use of this design is expected to be implemented and can be used in subsequent studies and can later be used properly.

\section{REFERENCES}

1. Chienwattanasook, K., Wattanapongphasuk, W., Prianto, A., \& Jermsittiparsert, K. 2019. "Corporate Entrepreneurship and Business Performance of Logistic Companies in Indonesia." Industrial Engineering \& Management Systems 18 (3): 538-547.

2. Dawabsheh, M., Hussein, A., \& Jermsittiparsert, K. 2019. "The Triangular Relationship between TQM, Organizational Excellence and Organizational Performance: A Case of Arab American University Palestine." Management Science Letters 9 (6): 921-932.

3. Jermsittiparsert, K., Siam, M., Issa, M., Ahmed, U., \& Pahi, M. 2019. "Do Consumers Expect Companies to Be Socially Responsible? The Impact of Corporate Social Responsibility on Buying Behavior." Uncertain Supply Chain Management 7 (4): 741-752.

4. Syazali, M., Putra, F., Rinaldi, A., Utami, L., Widayanti, Umam, R., \& Jermsittiparsert, K. 2019. "Partial Correlation Analysis Using Multiple Linear Regression: Impact on Business Environment of Digital Marketing Interest in the Era of Industrial Revolution 4.0." Management Science Letters 9 (11): 1875-1886.

5. Sae-Lim, P. \& Jermsittiparsert, K. 2019. "Is the Fourth Industrial Revolution a Panacea? Risks toward the Fourth Industrial Revolution: Evidence in the Thai Economy." International Journal of Innovation, Creativity and Change 5 (2): 732-752.

6. Chatchawanchanchanakij, P., Arpornpisal, C., \& Jermsittiparsert, K. 2019. "The Role of Corporate Governance in Creating a Capable Supply Chain: A Case of Indonesian Tin Industry." International Journal of Supply Chain Management 8 (3): 854-864.

7. Hartinah, S., Suharso, P., Umam, R., Syazali, M., Lestari, B., Roslina, R., \& Jermsittiparsert, K. 2020. “Teacher's Performance Management: The Role of Principal's Leadership, Work Environment and Motivation in Tegal City, Indonesia.” Management Science Letters 10 (1): 235-246.

8. Haseeb, M., Hussain, H., Slusarczyk, B., \& Jermsittiparsert, K. 2019. "Industry 4.0: A Solution towards Technology Challenges of Sustainable Business Performance.” Social Sciences 8 (5): 184.

9. Haseeb, M., Hussain, H., Kot, S., Androniceanu, A., \& Jermsittiparsert, K. 2019. "Role of Social and Technological Challenges in Achieving a Sustainable Competitive Advantage and Sustainable Business Performance." Sustainability 11 (14): 3811.

10. Haseeb, M., Kot, S., Hussain, H., \& Jermsittiparsert, K. 2019. "Impact of Economic Growth, Environmental Pollution, and Energy Consumption on Health Expenditure and $\mathrm{R}$ and D Expenditure of ASEAN Countries.” Energies 12 (19): 3598.

11. Huda, S., Tsani, I., Syazali, M., Umam, R., \& Jermsittiparsert, K. 2020. "The Management of Educational System Using Three Law Auguste Comte: A Case of Islamic Schools.” Management Science Letters 10 (3) (In press), DOI: 10.5267/j.msl.2019.9.018.

12. Usak, M., Kubiatko, M., Shabbir, M., Dudnik, O., Jermsittiparsert, K., \& Rajabion, L. 2019. "Health Care Service Delivery Based on the Internet of Things: A Systematic and Comprehensive Study." International Journal of Communication Systems 32 (14): e4179.

13. Jermsittiparsert, K., Ambarita, D., Mihardjo, L., \& Ghani, E. 2019 "Risk-Return through Financial Ratios as Determinants of Stock Price: A Study from ASEAN Region." Journal of Security and Sustainability Issues 9 (1): 199-210.

14. Thabhiranrak, T. \& Jermsittiparsert, K. 2019. “Towards Sustainable Functioning of Organization: Women Empowernment and Corporate Management Culture.” Journal of Security and Sustainability Issues 9 (1): 321-332.

15. Chienwattanasook, K. \& Jermsittiparsert, K. 2019. "Impact of Entrepreneur Education on Entrepreneurial Self-Employment: A Case Study from Thailand." Polish Journal of Management Studies 19 (1): 106-116.

16. Jermsittiparsert, K., Sutduean, J., Sriyakul, T., \& Khumboon, R. 2019. "The Role of Customer Responsiveness in Improving the External Performance of an Agile Supply Chain.” Polish Journal of Management Studies 19 (2): 206-217.

17. Jermsittiparsert, K., Sutduean, J., \& Sriyakul, T. 2019. "Effect of Service Innovation and Market Intelligence on Supply Chain Performance in Indonesian Fishing Industry." Industrial Engineering \& Management Systems 18 (3): 408-417. 
18. Jermsittiparsert, K., Namdej, P., \& Somjai, S. 2019. "Green Supply Chain Practices and Sustainable Performance: Moderating Role of Total Quality Management Practices in Electronic Industry of Thailand.” International Journal of Supply Chain Management 8 (3): 33-46.

19. Somjai, S. \& Jermsittiparsert, K. 2019. "The Trade-off between Cost and Environmental Performance in the Presence of Sustainable Supply Chain.” International Journal of Supply Chain Management 8 (4): 237-247.

20. Jermsittiparsert, K. \& Sawasdee, A. 2012. "Formal Education for Non-Thai or Undocumented Person in Thailand amidst the Challenge of Nationalism and Transnationalism: A Case Study of Wat Sirimongkhol School, Samut Sakhon Province.” Kasetsart Journal - Social Sciences 33 (2): 203-213.

21. Maseleno, A., Huda, M., Jasmi, K. A., Basiron, B., Mustari, I., Don, A G., \& bin Ahmad, R. (2019). Hau-Kashyap approach for student's level of expertise. Egyptian Informatics Journal, 20(1), 27-32.

22. Maseleno, A., Huda, M., Siregar, M., Ahmad, R., Hehsan, A., Haron, Z., ... \& Jasmi, K. A. (2017). Combining the previous measure of evidence to educational entrance examination. Journal of Artificial Intelligence, 10(3), 85-90

23. Maseleno, A., Hardaker, G., Sabani, N., \& Suhaili, N. (2016). Data on multicultural education and diagnostic information profiling: Culture, learning styles and creativity. Data in brief, 9, 1048. 